Jacobs, J., Borras-Santos, A., Krop, E., Täubel, M., Leppanen, H., Haverinen-Shaughnessy, U., Pekkanen, J., Hyvärinen, A., Doekes, G., Zock, J.P., Heederik, D. Dampness, bacterial and fungaty components in dust in primary schools and respiratory health in schoolchildren across Europe Occupational and Environmental Medicine: 2014, 71(10), 704-712

\begin{tabular}{|l|l|}
\hline $\begin{array}{l}\text { Postprint } \\
\text { Version }\end{array}$ & 1.0 \\
\hline Journal website & http://oem.bmi.com/content/71/10/704 \\
\hline Pubmed link & http://www.ncbi.nlm.nih.gov/pubmed/25035116 \\
\hline DOI & $10.1136 /$ oemed-2014-102246 \\
\hline
\end{tabular}

This is a NIVEL certified Post Print, more info at http://www.nivel.eu

\title{
Dampness, bacterial and fungal components in dust in primary schools and respiratory health in schoolchildren across Europe
}

\author{
José JACOBS1, ALICIA BORRÀs-SANTOS2,3,4, ESMERALDA KROP1, MARTIN TÄUBEL5, \\ Hanna Leppänen5, Ulla HaVerinen-Shaughnessy5, Juha PeKKanen5,6, Anne \\ HYVÄRINEN5, GERT DOEKES1, JAN-PAUL ZOCK2,3,4, DICK HEEDERIK1 \\ ${ }^{1}$ Division of Environmental Epidemiology, Institute for Risk Assessment Sciences, Utrecht \\ University, Utrecht, The Netherlands \\ ${ }^{2}$ Centre for Research in Environmental Epidemiology (CREAL), Barcelona, Spain \\ ${ }^{3}$ Hospital del Mar Research Institute (IMIM), Barcelona, Spain \\ ${ }^{4}$ CIBER Epidemiología y Salud Pública (CIBERESP), Barcelona, Spain \\ ${ }^{5}$ Department Environmental Health, National Institute for Health and Welfare, Kuopio, \\ Finland \\ ${ }^{6}$ Public Health and Clinical Nutrition, University of Eastern Finland, Kuopio, Finland
}

\section{Abstract}

Background Respiratory health effects of damp housing are well recognised, but less is known about the effect of dampness and water damage in schools. The HITEA study previously reported a higher prevalence of respiratory symptoms in pupils from moisture damaged schools, but the role of specific microbial exposures remained unclear.

Objectives To study associations between school dampness, levels of fungal and bacterial markers, respiratory symptoms and lung function in children.

Methods Primary schools in Spain, the Netherlands and Finland were selected on the basis of the observed presence $(n=15)$ or absence $(n=10)$ of moisture, dampness and/or mould. Settled dust was repeatedly sampled in 232 classrooms and levels of 14 different microbial markers and groups of microbes were determined. Parental reports of respiratory symptoms were available from 3843 children aged 6-12 years, of whom 2736 provided acceptable forced spirometry testing. Country-specific associations between exposure and respiratory health were evaluated by multilevel mixed-effects logistic and linear regression models and combined using random-effects meta-analysis.

Results The prevalence of respiratory symptoms was higher in moisture damaged schools, being more pronounced in Finnish pupils. Effects on lung function were not apparent. Levels of microbial markers were generally higher 
Jacobs, J., Borras-Santos, A., Krop, E., Täubel, M., Leppanen, H., Haverinen-Shaughnessy, U., Pekkanen, J., Hyvärinen, A., Doekes, G., Zock, J.P., Heederik, D. Dampness, bacterial and fungaty components in dust in primary schools and respiratory health in schoolchildren across Europe Occupational and Environmental Medicine: 2014, 71(10), 704-712

in moisture damaged schools, varied by season and were lower in Finnish schools. Wheeze tended to be inversely associated with microbial levels. All other respiratory symptoms were not consistently associated with microbial marker levels.

Conclusions Health effects of moisture and microbial exposures may vary between countries, but this requires further study.

\section{WHAT THIS PAPER ADDS}

- Several studies found consistent evidence for an association between dampness and mould observations in buildings and adverse effects on respiratory health in domestic and occupational settings; little is known about health effects related to exposure in school buildings.

- We studied associations between school dampness, microbial exposure and respiratory health in children.

- Associations were found between school dampness and respiratory symptoms, but not with lung function. These associations were not explained by levels of a range of (molecular) microbial markers.

- Our results indicate that associations between moisture, microbial exposure and health may vary between countries, meaning that future studies on microbial exposure across different regions and countries should also take into account differences in culture, climate and building use.

\section{INTRODUCTION}

Numerous studies in dwellings have found consistent associations between reported dampness in buildings and respiratory symptoms, asthma and allergies.1-4 Associations between dampness and respiratory symptoms have been observed in some school studies,5-7 but potential causal agents and mechanisms leading to health effects have not been studied extensively, particularly in schools.2-4 ,8 Only a few studies have examined microbial agents in school environments in relation to health effects.9-12

We previously found a higher prevalence of respiratory symptoms in children attending schools affected by moisture damage. Effects were more pronounced in Finnish schools.13 However, quantitative microbial exposure assessment and objective respiratory health assessment were not considered. The aim of this study was to explore associations between school dampness and respiratory health, and to explore whether long-term microbial exposure in the school environment can explain associations between dampness and respiratory health. Levels of bacterial and fungal markers in airborne settled school dust were measured, including endotoxin, $\beta-(1,3)-$ glucans, ergosterol and eleven DNA based assays for specific microbial groups and species using quantitative qPCR. Microbial exposure was measured in 232 classrooms, corresponding to a population of 3843 children with assessment of respiratory health and acceptable lung function measurements of 2736 children. 
Jacobs, J., Borras-Santos, A., Krop, E., Täubel, M., Leppanen, H., Haverinen-Shaughnessy, U., Pekkanen, J., Hyvärinen, A., Doekes, G., Zock, J.P., Heederik, D. Dampness, bacterial and fungaty components in dust in primary schools and respiratory health in schoolchildren across Europo Occupational and Environmental Medicine: 2014, 71(10), 704-712

\section{METHODS}

\section{Study design and population}

Participating schools were selected as described earlier.14 Briefly, 57 schools with and without dampness and moisture damage problems were selected for on-site inspections, based on building questionnaire data. They were all schools that were willing to participate, had more than 200 pupils, and had not planned major repairs or renovations during the period of the study. Schools were categorised as damaged (index schools) or non-damaged schools (reference schools), based on the number, extent, severity and location of dampness and moisture damage observations during the inspector's visits. All children from the first to sixth grade (aged \pm 6 to \pm 12 years) were invited to complete a parent-administered questionnaire. In the next phase, 14 index and 11 reference schools were selected for more detailed exposure and health characterisation. In Spain, the Netherlands and Finland, 8, 11 and 6 schools, respectively, participated.

The design of the HITEA school is presented in the online supplemental material, p.3.

\section{Respiratory health assessment}

The questionnaire survey was carried out during the fall of 2008 and was based on the validated International Study of Asthma and Allergy in Children questionnaire.15 Wheeze, congestion/phlegm, nocturnal dry cough and rhinitis during the past 12 months were considered as the health outcome (see online supplement, p.6 for complete definitions).

Lung function tests were performed in winter/early spring 2009. The forced expiratory volume in $1 \mathrm{~s}$ (FEV1), forced vital capacity (FVC), forced expiratory flow 25-75\% and the peak expiratory flow were measured using NDD EasyOne (Andover, Massachusetts, USA) spirometers following the European Respiratory Society guidelines.16 All lung function manoeuvres were reviewed manually by one lung function expert. Only sessions which led to at least two acceptable tests and a reproducibility of the FEV1 and FVC within $200 \mathrm{~mL}$ were considered for further analyses.

\section{Dust collection, extraction and analysis}

Dust was collected during three different periods: winter/early spring 2009 (exposure assessment (EA1)), late spring 2009 (EA2) and winter/early spring 2010 (EA3). Airborne dust was passively sampled on surfaces at a minimum height of $150 \mathrm{~cm}$ above floor level in 25 schools simultaneously for 8 weeks with electrostatic dust fall collectors (EDC)17 and settled dust boxes (SDB).18 Sampling devices were placed on approximately 15 locations per school, including classrooms. In total, 232 classrooms and 77 pooled classroom areas were sampled using EDCs and SDBs, respectively. At the local study centre, cloths were removed from the EDCs, dust was vacuumed from the SDBs, suspended in buffer and stored at $-20^{\circ} \mathrm{C}$. Detailed 
Jacobs, J., Borras-Santos, A., Krop, E., Täubel, M., Leppanen, H., Haverinen-Shaughnessy, U., Pekkanen, J., Hyvärinen, A., Doekes, G., Zock, J.P., Heederik, D. Dampness, bacterial and fungaty components in dust in primary schools and respiratory health in schoolchildren across Europo Occupational and Environmental Medicine: 2014, 71(10), 704-712

information on extraction and analyses of dust samples can be found in the online supplemental material, p.3).

EDC extracts were tested for endotoxin content using a limulus amoebocyte lysate assay (Lonza Group, Basel, Switzerland) according to the manufacturer's protocol, and expressed in endotoxin units (EU). Glucans were analysed with a specific $\beta$ (1,3)-glucan sandwich enzyme immunoassay (EIA) as previously described.19 The limit of detection (LOD) of the assay was $300 \mathrm{EU} / \mathrm{m}^{2}$ for endotoxin and $200 \mathrm{ng} / \mathrm{m}^{2}$ for glucans. Endotoxin could be detected in all classroom samples. Four (2\%) of the glucan samples were below the LOD and were assigned a value of $133 \mathrm{ng} / \mathrm{m}^{2}$.

Ergosterol was analysed by gas chromatography in combination with an ion trap mass spectrometer as described earlier.20

Dust from SDBs was pooled for predefined clusters of classrooms in the same area of a school, resulting in 77 pooled classroom areas. In these pooled dust samples DNA from Cladosporium herbarum, Eurotium amstelodami, Stachybotrys chartarum, Wallemia sebi, Penicillium chrysogenum, group Trichoderma viride/atroviride/koningii, group Penicillium spp./Aspergillus spp./Paecilomyces variotii, Mycobacterium spp., Streptomyces spp., Gram-positive bacteria and Gramnegative bacteria was measured by using quantitative PCR methods.

\section{Covariables and confounding e}

In each school, indoor $\mathrm{PM}_{2.5}$, soot, $\mathrm{NO}_{2}$ and $\mathrm{CO}_{2}$ were measured during five consecutive schooldays to study whether ventilation and traffic-related exposure can confound associations between microbial school levels and health. Detailed information on the exposure assessment of the $\mathrm{CO}_{2}$ and traffic-related indices can be found in the online supplemental material, p.5.

\section{Statistical analysis}

The distribution of the microbial markers was highly skewed and therefore log transformed. Spearman correlations coefficients were determined to evaluate the correlation between exposure markers. In order to calculate average exposure levels, left-censored regression (tobit) models were used to take into account the large proportion of undetectable values for some of the microbial markers.

The school average of all classrooms sampled during the three repeated measurements was used for the DNA-based (qPCR) microbial determinations and ergosterol and classroom-specific exposure from the first exposure assessment was used for endotoxins and glucans.

'Total microbial exposure' was assessed by creating a 'sum score' variable as a marker for multiple microbial signals. For each marker, exposure was categorised as low (1), medium (2) or high (3) based on country-specific tertiles. In Finland, most microbial markers were detected in very few samples and therefore categorised as non-detectable (0) or detectable (1). Only endotoxin, glucan, Gram positive and 
Jacobs, J., Borras-Santos, A., Krop, E., Täubel, M., Leppanen, H., Haverinen-Shaughnessy, U., Pekkanen, J., Hyvärinen, A., Doekes, G., Zock, J.P., Heederik, D. Dampness, bacterial and fungaty components in dust in primary schools and respiratory health in schoolchildren across Europe Occupational and Environmental Medicine: 2014, 71(10), 704-712

negative bacteria levels were categorised based on tertiles in Finland. Since DNA from Penicillium chrysogenum, Stachbotrys chartarum, Trichoderma viride and Wallemia sebi were detected in less than $50 \%$ of the samples in each country, these were always categorised as non-detectable (0) or detectable (1) as well.

Country-specific associations were evaluated using ORs for symptoms and regression coefficients for lung function variables with 95\% CI, obtained by multilevel mixed-effects logistic and linear regression. Effect estimates were combined and potential heterogeneity effects between countries $(p<0.10)$ were studied by using standardised methods for random-effects meta-analysis (Hedges 1998). Associations with symptoms were adjusted for gender, age, parental educational level (as an indicator for socioeconomic level) and moisture damage in the home. This selection was based on the confounders considered in our previous study.13 For lung function, height, the assisting technician and passive smoking were included as well. For all associations 'school' was included as a group variable to adjust for correlations within schools. Health effects estimates were expressed as the change associated with an IQR increase in microbial exposure per country.

Additional analyses were performed limited to asthmatics or children with wheeze, excluding children with moisture and mould at home or those who recently used asthma medication, to study whether associations might be limited to susceptible groups or whether effect-modification played a role. We also performed stratified analyses by gender, age group, parental education or maternal asthma.

Statistical analyses were performed with SAS V.9.2 and STATA V.10.1 for the meta-analyses.

\section{RESULTS}

\section{Microbial exposure}

Levels of microbial markers in classrooms differed strongly between countries and were higher in Spain and the Netherlands compared with Finland (table 1). Endotoxin, ergosterol and Penicillium chrysogenum DNA levels were higher in classrooms of index compared with reference schools in all three countries, although differences were not always statistically significant. Generally, the majority of PCRmarkers were higher in index schools, but the differences were mostly not significant. Most consistent differences between index and reference schools were seen in Dutch schools, but they were generally smaller than a factor of two for most markers.

\section{[TABLE 1]}

Between schools, differences in microbial levels were larger. For instance, Gram positive and negative bacteria DNA levels differed by a factor of 4-5 between schools with the highest and lowest measured exposure in each of the three countries. In Spain and the Netherlands, Cladosporium herbarum DNA and group Penicillium spp/Aspergillus spp/P. variotii DNA differed by a factor of 5 between schools with 
Jacobs, J., Borras-Santos, A., Krop, E., Täubel, M., Leppanen, H., Haverinen-Shaughnessy, U., Pekkanen, J., Hyvärinen, A., Doekes, G., Zock, J.P., Heederik, D. Dampness, bacterial and fungaty components in dust in primary schools and respiratory health in schoolchildren across Europo Occupational and Environmental Medicine: 2014, 71(10), 704-712

the lowest and highest levels, whereas DNA levels of Mycobacterium spp and Streptomyces spp differed by a factor of more than 10. Even larger exposure differences between schools existed for types of microbial markers that were detected in only a part of the samples (data not shown). Endotoxin and glucans and DNA from Gram positive and negative bacteria were highly correlated in each country ( $r>0.66$ and $r>0.85$, respectively; see online supplementary table S1). Correlations between other microbial markers differed between countries.

\section{Study population characteristics}

Health questionnaires were received from 3843 children (response rate: 62\%). Information on lung function was obtained from 3538 children (response rate: 57\%). From 2736 children, valid and reproducible lung function measurements and confounder information were available.

Exposure to passive smoking at home was more common in Spain and the Netherlands than in Finland (table 2). Moisture damage or mould at home was reported by $4 \%$ of the Finnish participants, while in Spain and the Netherlands 19\% of the participants reported moisture or mould at home during the past year.

\section{[TABLE 2]}

Nasal symptoms were reported more frequently in Finland compared with Spain and the Netherlands (33\% vs 23\%). Also, current wheeze (13\%), congestion and phlegm (10\%) and asthma prevalence (8\%) were slightly higher in Finland compared with Spain and the Netherlands, while the frequency of nocturnal dry cough was lowest in the Finnish children, that is, $13 \%$ compared with $19 \%$ in the Netherlands and $21 \%$ in Spain. Asthma and congestion and phlegm were lowest in Spain (4\% and 6\%, respectively), while in the Netherlands wheeze was reported less frequently (9\%) compared with the other two countries.

\section{Dampness, microbial exposure and respiratory health}

In general, respiratory symptoms were reported more often in pupils attending schools affected by moisture, but meta-associations were only significant for dry cough at night (OR 1.31; 95\% CI 1.04 to 1.64; figure 1A). Country-specific associations were mainly significant in Finland. No associations were found between school moisture and lung function (figure 1B).

\section{[FIGURE 1]}

Association between moisture at school and respiratory health. Forest plots of country-specific ORs and estimates (EST) (95\% CI). The box area is proportional to the statistical weight for the individual study. The diamond indicates the $95 \%$ CI of the combined risk estimate from the model, with county as a random effect; * = p for heterogeneity $<0.10$.

Symptom prevalence during the past 12 months was not clearly associated with microbial exposure (figure 2 and see online supplementary figure S1). Increased 
Jacobs, J., Borras-Santos, A., Krop, E., Täubel, M., Leppanen, H., Haverinen-Shaughnessy, U., Pekkanen, J., Hyvärinen, A., Doekes, G., Zock, J.P., Heederik, D. Dampness, bacterial and fungaty components in dust in primary schools and respiratory health in schoolchildren across Europo Occupational and Environmental Medicine: 2014, 71(10), 704-712

exposure tended to be associated with less symptoms, especially for wheeze and especially in Spanish schools. In Spain also, prevalence of phlegm and nocturnal dry cough was lower when exposure was higher; associations with combined microbial exposure were significant (sum score; ORs between 0.63 and 0.68). However, there was no clear consistency overall across countries and between specific microbial markers. Exploring associations separately for sum scores of fungal or bacterial DNA markers did not clearly change associations (data not shown).

\section{[FIGURE 2]}

No clear and statistically significant associations were found between microbial exposure and lung function (figure 3).

\section{[FIGURE 3]}

Association between measured microbial levels and lung function, Forest plots of country-specific estimates (est) $(95 \% \mathrm{CI})$ for the effect of measured microbial levels (IQR increase). The box area is proportional to the statistical weight for the individual study. The diamond indicates the $95 \% \mathrm{CI}$ of the combined risk estimate from the model, with county as a random effect; $*=p$ for heterogeneity $<0.10$.

Inclusion of microbial markers did not change moisture-health associations for symptoms or for lung function (see online supplementary table S2, figure S2). There were also no indications for non-linear exposure-health associations when the prevalence of wheeze was explored in relation to tertiles of endotoxin, glucan and total sum score of exposure (data not shown). Taking into account $\mathrm{CO}_{2}$ and trafficrelated exposures, such as indoor $\mathrm{PM}_{2.5}$, soot or $\mathrm{NO}_{2}$ levels, as potential determinants that can affect respiratory health (as confounder) did not change the association between moisture and health either (data not shown).

\section{Sensitivity analyses}

Analyses limited to asthmatics or children with wheeze did not indicate that symptoms or lung function were associated with moisture damage or microbial exposure in these subgroups. Also, excluding children with moisture and mould at home or those who recently used asthma medication did not alter associations between school dampness, lung function or symptom prevalence (data not shown). Stratification by gender, age group, parental education or maternal asthma (see online supplementary figure S3) did not indicate that results were explained by effect modification.

\section{DisCUSSION}

This is the largest study in Europe that has been performed on dampness and microbial markers in schools, with strong and detailed exposure and health assessment components. Symptom and lung function data were available for 3843 and 2736 children, respectively, and microbial markers were repeatedly measured in almost 700 samples from more than 200 measurement locations over three seasons. 
Jacobs, J., Borras-Santos, A., Krop, E., Täubel, M., Leppanen, H., Haverinen-Shaughnessy, U., Pekkanen, J., Hyvärinen, A., Doekes, G., Zock, J.P., Heederik, D. Dampness, bacterial and fungaty components in dust in primary schools and respiratory health in schoolchildren across Europo Occupational and Environmental Medicine: 2014, 71(10), 704-712

Schools that experienced dampness problems were oversampled, resulting in an increased potential to find associations between dampness and microbial markers. This means that the power of this study is high and that it can thus be considered as highly informative. Despite this power, we did not find clear associations between microbial exposure and respiratory health.

Respiratory symptoms in schoolchildren were reported more frequently in schools that were affected by moisture and mould, but mainly in Finland. Paradoxically, measured microbial levels in Finnish schools were considerably lower than in Spanish and Dutch schools and the differences between index and reference schools were not consistent. Although microbial levels tended to be higher in damp schools, significant differences between schools with and without dampness were predominantly found in Dutch schools. The microbial markers measured in this study and determined from settled dust in classrooms were not able to explain the observed association between moisture and mould and increased risk of respiratory symptoms in pupils. There was a suggestion that respiratory symptoms decreased with increasing microbial exposure, particularly for wheeze, but these findings were not significant and not consistent between countries. No associations of moisture and mould or microbial growth with lung function in schoolchildren were observed.

The associations between moisture at school and symptoms that we found previously were confirmed in the subsample of schools and children in this study.13 Previously, we found a significant and consistent association with school moisture and dry cough at night (OR 1.15; 95\% CI 1.00 to 1.33). In this study, we also found borderline significant associations with recent cough, phlegm and nasal symptoms. These associations are likely to be related to the selection of schools; in this follow-up survey, exposure contrast was increased by selecting index schools that were most affected by dampness, moisture damage and mould, whereas the least affected schools were selected as reference schools.

We did not observe associations between school dampness and lung function. Consistent with this, no associations have been found between dampness and lung function in children and teachers in previous school studies.21-23 Few studies have investigated associations between home dampness and lung function;1,24,25 although lung function tended to be lower in children living in damp houses, the evidence for an association is considered inconsistent. 4

A limited number of previous studies have examined microbial exposures in schools and the impact on health, with conflicting results. Some found positive associations between (viable and non-viable) microbial levels and respiratory symptoms,5, 10, 12 while negative associations between viable bacteria, moulds and respiratory symptoms in pupils have also been found.26

Endotoxin in the school environment is likely to contribute considerably to the total burden of endotoxin exposure. Levels are higher in schools than in bedrooms from schoolchildren27,28 and school endotoxin levels were also associated with nonatopic asthma symptoms in a Dutch subsample of children in this study.28 We do not 
Jacobs, J., Borras-Santos, A., Krop, E., Täubel, M., Leppanen, H., Haverinen-Shaughnessy, U., Pekkanen, J., Hyvärinen, A., Doekes, G., Zock, J.P., Heederik, D. Dampness, bacterial and fungaty components in dust in primary schools and respiratory health in schoolchildren across Europe Occupational and Environmental Medicine: 2014, 71(10), 704-712

have information on atopic status for the complete study population, so in this study we cannot differentiate between atopic and non-atopic symptoms.

A study of 10 Chinese schools showed protective effects of microbial exposure to muramic acid and ergosterol in combined dust from floors, chairs and desks of 39 classrooms on asthma symptoms of 1993 pupils, while the effect of endotoxin lipopolysaccharides (LPS) depended on the chain length of the fatty acid chains of the LPS molecules.11 We were not able to reproduce these associations between endotoxin exposure and asthma-like symptoms.

Microbial DNA targets were measured in only two other studies. Aspergillus versicolor DNA and Streptomyces DNA measured in petri dish dust samples during 1 week in 32 classrooms of 8 Malaysian schools were associated with respiratory symptoms in 462 children aged 14-16.12 Associations between S. chartarum DNA and daytime breathlessness were inverse. A study that investigated 46 classrooms in 21 schools in 5 European countries found inverse associations between $A$. versicolor DNA and Streptomyces DNA in floor dust and lung function.10 Furthermore, Aspergillus/Penicillium DNA was significantly associated with wheeze, and $A$. versicolor DNA was significantly associated with wheeze, rhinitis and cough.

Dampness is one of the main contributors of microbial growth in buildings. In our study, levels of microbial markers varied considerably between countries, with the lowest levels being found in Finland. The differences between index and reference schools within countries were, however, relatively small with only consistent findings in the Netherlands. Other studies, mainly in Scandinavia, have found differences in microbial markers between schools with dampness and reference schools,18, 29,30 but here also the differences were small. In addition, viable moulds were measured or active air sampling was used, so they cannot be directly compared with our results. Higher levels of viable moulds and total fungal DNA were found in buildings with mould or dampness problems in another pan-European study.10 Like in our study, a north-south gradient in exposure was found, with the lower levels in the Nordic countries. This was only the case for viable moulds and not for total fungal DNA. Nevertheless, effects of dampness and country were not mutually adjusted and it remains unclear whether the schools affected by dampness were heterogeneously distributed over countries, possibly resulting in biased estimates of the effects of dampness and the north-south differences.

Several factors may explain the large differences in microbial levels between countries, and the relatively small differences between damp and reference schools within a country. The microbes and microbial markers we measured-an extensive set-still characterise the dampness-related microbial exposure only to a limited extent, as previously found for homes.31 At the same time, it is known that microbial levels indoors are determined by a variety of factors that may vary between countries. In home dust, a considerable part of the bacteria is of human origin.32 In schools, which are places with a high occupant density, a large part of the (particularly bacterial) microbes is most likely of human origin (derived from occupants' skin, hair, breathing and clothes). Moreover, microbial growth on building materials is typically diverse and complex because it can be influenced by 
Jacobs, J., Borras-Santos, A., Krop, E., Täubel, M., Leppanen, H., Haverinen-Shaughnessy, U., Pekkanen, J., Hyvärinen, A., Doekes, G., Zock, J.P., Heederik, D. Dampness, bacterial and fungaty components in dust in primary schools and respiratory health in schoolchildren across Europe Occupational and Environmental Medicine: 2014, 71(10), 704-712

the nature of the moisture problem, type and use of materials, outdoor sources and several other factors.33,34 In our study, for instance, the type of moisture problems in schools differed between the three countries. In Spain, a relatively high prevalence of moisture or water damage from outside sources and rising damp occurred. In the Netherlands, the schools commonly reported signs of dampness (like condensation on windows), while mould odour was relatively commonly reported in Finnish schools.14 This might have resulted in the different microbial exposure patterns that were found in our study. In Finland, snow coverage during a long period of the year most likely contributed to the lower microbial marker levels compared with Spain and the Netherlands.

Microbial exposure is also affected by cultural differences and building use. Finnish children change shoes at the entrance, which is not common in Spain and the Netherlands. This most likely influenced the 'influx' of soil and associated microorganisms into the indoor environment and in indoor dust. In all Finnish schools, mechanical ventilation with filtered incoming air was present, while a substantial part of the Spanish and Dutch schools only had natural ventilation (opening windows) and no filtering of the supply air. Even though the literature lacks dedicated and conclusive studies on this subject, it can be expected that the type of ventilation as well as air exchange rates affects microbial levels indoors.35,36

Even though the overall microbial levels were low and differences between index and reference schools were inconsistent, the associations between moisture damage and respiratory symptoms were strongest in Finland. The three countries seem to have markedly different exposure patterns for most microbial markers and groups. While in Spain and the Netherlands exposure is always relatively high and measurable, microbial exposure during winter in Finland generally seems to be very low. It can be hypothesised that this different pattern in exposure between countries might contribute to the difference in symptoms occurrence and relations with school dampness and microbial exposure. Also, the dry and cold conditions in Finland, mainly during winter, might have predisposed children to suffer from symptoms more easily, particularly in damp schools as a result of possible (unmeasured and unmeasurable) exposure. In addition, possibly higher microbial levels and diversity in Spain and the Netherlands are protecting, to some extent, against development of respiratory and allergic symptoms. We found a tendency of lower symptoms prevalence in relation to higher microbial levels in schools (particularly in Spain), and this was also found in previous studies in farms and homes.37 ,38 One could hypothesise that (early-life) microbial exposure in Finland is generally lower due to less contact with different microbe-rich environments (like daycare centres (table 2)), which could result in less protection against development of respiratory symptoms later in life.39 This pattern of lower and larger temporal microbial exposure in Finland might influence development of tolerance and susceptibility of children despite the low levels of microbial exposure.

The effect of dampness on microbial exposure was small, generally smaller than a factor of two for most markers in the Netherlands, where associations with dampness seemed to be most clear and present. The IQR in exposure between all measurement locations was higher and ranged between 0 and 60, dependent on the microbial 
Jacobs, J., Borras-Santos, A., Krop, E., Täubel, M., Leppanen, H., Haverinen-Shaughnessy, U., Pekkanen, J., Hyvärinen, A., Doekes, G., Zock, J.P., Heederik, D. Dampness, bacterial and fungaty components in dust in primary schools and respiratory health in schoolchildren across Europo Occupational and Environmental Medicine: 2014, 71(10), 704-712

marker or group considered (data not shown), indicating that despite the absence of a dampness effect, there is a contrast in microbial exposure within this study and that the study had sufficient contrast in exposure to pick up associations between symptoms and lung function differences related to microbial exposure. We only studied schools that had no planned renovations during the entire survey period of the HITEA school study, which was 2 years due also to longitudinal elements in the study design, which will be reported elsewhere. Schools with more severe moisture problems that would require immediate or intermediate counteraction were not able to participate in this study, resulting in lower moisture damage exposure contrast and subsequently lower contrast in microbial contamination.

In our study, settled dust was measured at a sampling height of at least $1.50 \mathrm{~m}$. This might better reflect inhalable microbial exposure compared with dust sampled from floors or mattresses.17 To reduce temporal variation, which is a limitation of studies that measure exposure by active sampling, dust was sampled for 8 weeks Although dust was sampled when children were absent, it was shown in an earlier study that exposure was negligible during weekends and nights, indicating that sampling 8 weeks continuously did not distort the exposure estimations.40 Also, cleaning methods and frequency might affect dust levels.41 Despite the potential effects of these factors, good correlations were described earlier between endotoxin measurements from settled dust collected on the EDC and 'true exposure' by actively sampled $\mathrm{PM}_{10}$ airborne dust, indicating that the used sampling methods are a good alternative for floor dust measurements.17,42

Earlier studies found associations between microbial exposure assessed on a more detailed level (eg, classroom level) and health symptoms.10-12 In this study, pooling of settled dust collected with the SDB was performed in order to collect the necessary amount of dust. Therefore it was, except for endotoxin and glucans, not possible to study associations between the individual classroom levels and specific health outcomes of students. Refined analyses that included only the exposure measurement taken during the health survey, and exposure averages based on clusters of pooled classroom samples instead of overall school averages, did not change the results.

As was found in other studies, moisture at the homes of study participants was associated with the prevalence of several symptoms (data not shown). In 20\% of the houses of the Spanish and Dutch participants, moisture or mould was reported, which might bias our associations between school moisture and health. Therefore, analyses were also performed excluding this group. The tendency of the associations, however, was comparable as for the whole data set.

The response rate of our study was $60 \%$. A comparison of symptoms of the participants and non-participants of the lung function tests revealed no major differences between the two groups. The possibility of over-reporting symptoms in moist schools as a result of public awareness, as well as selective avoidance of schools with dampness problems by symptomatic children, cannot be ruled out completely in this study. 
Jacobs, J., Borras-Santos, A., Krop, E., Täubel, M., Leppanen, H., Haverinen-Shaughnessy, U., Pekkanen, J., Hyvärinen, A., Doekes, G., Zock, J.P., Heederik, D. Dampness, bacterial and fungaty components in dust in primary schools and respiratory health in schoolchildren across Europe Occupational and Environmental Medicine: 2014, 71(10), 704-712

In conclusion, this study can be considered highly informative, being unique in that it explored microbial exposure in primary schools qualitatively and quantitatively in great detail and with a strong and detailed exposure assessment strategy. Our results indicate that associations between moisture, microbial exposure and health may vary between regions and countries. We found associations between observed dampness in schools and respiratory symptoms, in the absence of effects on lung function, with associations mainly being observed in Finland. The microbial exposure as determined in this study did not explain the observed associations between dampness and respiratory symptoms; less wheezing was observed when microbial levels were higher. Associations for other respiratory symptoms and lung function were not consistent. It was hypothesised that the exceptional exposure pattern in Finland, with very low exposure during winter, as well as low microbial levels during warmer periods of the year, might have contributed to symptom occurrence; however, this requires further longitudinal studies.

\section{FOOTNOTES}

- Contributors All co-authors have read and approved the final version of this manuscript. Each co-author contributed substantially to the design of the analysis, the interpretation of the results, and the preparation of the final manuscript.

- Funding This work was supported by the European Commission as part of HITEA (Health Effects of Indoor Pollutants: Integrating microbial, toxicological and epidemiological approaches), Grant agreement no. 211488 under the Seventh Framework Programme, Topic ENV.2007.1.2.1.1. 'Indoor air pollution in Europe: An emerging environmental health issue. JJ had an ERS and LFN short-term research fellowship to work on this paper.

- Competing interests None.

- Patient consent Obtained.

- Ethics approval The study protocol was approved by the Local Medical Ethical Committee in each country and complied with all requirements of international regulations (in the Netherlands-UMC Utrecht, in Spain and Finland to be checked).

- Provenance and peer review Not commissioned; externally peer reviewed.

\section{REFERENCES}

1. Brunekreef B, Dockery DW, Speizer FE, et al . Home dampness and respiratory morbidity in children. Am Rev Respir Dis 1989;140:1363-7.

2. Institute of Medicine. Damp indoor spaces and health. Washington, DC: National Academy Press, 2004.

3. World Health Organization. WHO guidelines for indoor air quality: dampness and mould. Copenhagen: World Health Organization, 2009.

4. Mendell MJ, Mirer AG, Cheung K, et al. Respiratory and allergic health effects of dampness, mold, and dampness-related agents: a review of the epidemiologic evidence. Environ Health Perspect 2011;119:748-56.

5. Smedje G, Norback D, Edling C . Asthma among secondary schoolchildren in relation to the school environment. Clin Exp Allergy 1997;27:1270-8. 
Jacobs, J., Borras-Santos, A., Krop, E., Täubel, M., Leppanen, H., Haverinen-Shaughnessy, U., Pekkanen, J., Hyvärinen, A., Doekes, G., Zock, J.P., Heederik, D. Dampness, bacterial and fungaty components in dust in primary schools and respiratory health in schoolchildren across Europe Occupational and Environmental Medicine: 2014, 71(10), 704-712

6. Sahakian NM, White SK, Park JH, et al . Identification of mold and dampnessassociated respiratory morbidity in 2 schools: comparison of questionnaire survey responses to national data. J Sch Health 2008;78:32-7.

7. Meklin T, Potus T, Pekkanen J, et al . Effects of moisture-damage repairs on microbial exposure and symptoms in schoolchildren. Indoor Air 2005;15(Suppl 10):40-7.

8. Fisk WJ, Lei-Gomez Q, Mendell MJ . Meta-analyses of the associations of respiratory health effects with dampness and mold in homes. Indoor Air 2007;17:284-96.

9. Rylander R . Indoor air-related effects and airborne (1-> 3)-beta-D-glucan. Environ Health Perspect 1999;107(Suppl 3):501-3.

10. Simoni M, Cai $G H$, Norback $D$, et al . Total viable molds and fungal DNA in classrooms and association with respiratory health and pulmonary function of European schoolchildren. Pediatr Allergy Immunol 2011;22:843-52.

11. Zhao Z, Sebastian A, Larsson $L$, et al . Asthmatic symptoms among pupils in relation to microbial dust exposure in schools in Taiyuan, China. Pediatr Allergy Immunol 2008;19:455-65.

12. Cai GH, Hashim JH, Hashim Z, et al . Fungal DNA, allergens, mycotoxins and associations with asthmatic symptoms among pupils in schools from Johor Bahru, Malaysia. Pediatr Allergy Immunol 2011;22:290-7.

13. Borràs Santos $A$, Jacobs $\mathrm{JH}$, Taubel $\mathrm{M}$, et al . Dampness and mould in primary schools and respiratory symptoms in children: the European HITEA study. Occup Environ Med 2013;70:681-7.

14. Haverinen-Shaughnessy U, Borras-Santos A, Turunen M, et al . Occurrence of moisture problems in schools in three countries from different climatic regions of Europe based on questionnaires and building inspections-the HITEA study. Indoor Air 2012;22:457-66.

15. Asher MI, Keil U, Anderson HR, et al . International Study of Asthma and Allergies in Childhood (ISAAC): rationale and methods. Eur Respir J 1995;8:483-91.

16. Miller MR, Hankinson J, Brusasco V, et al . Standardisation of spirometry. Eur Respir J 2005;26:319-38.

17. Noss I, Wouters IM, Visser M, et al . Evaluation of a low-cost electrostatic dust fall collector for indoor air endotoxin exposure assessment. Appl Environ Microbiol 2008;74:5621-7.

18. Würtz $H$, Sigsgaard $T$, Valbjørn $O$, et al . The dustfall collector-a simple passive tool for long-term collection of airborne dust: a project under the Danish Mould in Buildings program (DAMIB). Indoor Air 2005;15:33-40.

19. Noss I, Wouters IM, Bezemer G, et al . beta-(1,3)-Glucan exposure assessment by passive airborne dust sampling and new sensitive immunoassays. Appl Environ Microbiol 2010;76:1158-67.

20. Lappalainen MH, Hyvarinen A, Hirvonen MR, et al. High indoor microbial levels are associated with reduced Th1 cytokine secretion capacity in infancy. Int Arch Allergy Immunol 2012;159:194-203.

21. Ebbehøj NE, Meyer HW, Würtz $\mathrm{H}$, et al . Molds in floor dust, building-related symptoms, and lung function among male and female schoolteachers. Indoor Air Suppl 2005;15:7-16.

22. Immonen J, Taskinen $\mathrm{T}$, Pekkanen $\mathrm{J}$, et al . Bronchial reactivity in students from moisture and mold-damaged schools: Changes in relation to changes in exposure. Pediatr Asthma Allergy Immunol 2004;17:116-25.

23. Patovirta RL, Husman $T$, Haverinen $U$, et al . The remediation of mold damaged school-a three-year follow-up study on teachers' health. Cent Eur J Public Health 2004;12:36-42.

24. Andriessen JW, Brunekreef B, Roemer W. Home dampness and respiratory health status in European children. Clin Exp Allergy 1998;28:1191-200.

25. Verhoeff AP, Van Strien RT, Van Wijnen JH, et al . Damp housing and childhood respiratory symptoms: the role of sensitization to dust mites and molds. Am J Epidemiol 1995;141:103-10. 
Jacobs, J., Borras-Santos, A., Krop, E., Täubel, M., Leppanen, H., Haverinen-Shaughnessy, U., Pekkanen, J., Hyvärinen, A., Doekes, G., Zock, J.P., Heederik, D. Dampness, bacterial and fungaty components in dust in primary schools and respiratory health in schoolchildren across Europe Occupational and Environmental Medicine: 2014, 71(10), 704-712

26. Kim JL, Elfman L, Mi Y, et al . Indoor molds, bacteria, microbial volatile organic compounds and plasticizers in schools-associations with asthma and respiratory symptoms in pupils. Indoor Air 2007;17:153-63.

27. Sheehan WJ, Hoffman EB, Fu C, et al . Endotoxin exposure in inner-city schools and homes of children with asthma. Ann Allergy Asthma Immunol 2012;108:418-22.

28. Jacobs JH, Krop EJM, Spithoven JJ, et al. Endotoxin levels in homes and classrooms of Dutch school children and respiratory health. Eur Respir J 2013;42:314-22.

29. Lignell $U$, Meklin T, Putus $\mathrm{T}$, et al . Effects of moisture damage and renovation on microbial conditions and pupils' health in two schools-a longitudinal analysis of five years. J Environ Monit 2007;9:225-33.

30. Meklin $\mathrm{T}$, Hyvärinen A, Toivola $\mathrm{M}$, et al . Effect of building frame and moisture damage on microbiological indoor air quality in school buildings. AlHA J (Fairfax, Va) 2003;64:108-16.

31. Sordillo JE, Alwis UK, Hoffman E, et al. Home characteristics as predictors of bacterial and fungal microbial biomarkers in house dust. Environ Health Perspect 2011;119:189-95.

32. Täubel $M$, Rintala $H$, Pitkäranta $M$, et al . The occupant as a source of house dust bacteria. J Allergy Clin Immunol 2009;124:834-840.e47.

33. Nevalainen A, Seuri M . Of microbes and men. Indoor Air 2005;15:58-64.

34. Amend AS, Seifert KA, Samson R, et al . Indoor fungal composition is geographically patterned and more diverse in temperate zones than in the tropics. Proc Natl Acad Sci U S A 2010;107:13748-53.

35. Meyer HW, Suadicani P, Nielsen PA, et al . Moulds in floor dust-a particular problem in mechanically ventilated rooms? A study of adolescent schoolboys under the Danish moulds in buildings program. Scand J Work Environ Health 2011;37:332-40.

36. Wu PC, Li YY, Chiang CM, et al. Changing microbial concentrations are associated with ventilation performance in Taiwan's air-conditioned office buildings. Indoor Air 2005;15:19-26.

37. Braun-Fahrlander C, Riedler J, Herz U, et al . Environmental exposure to endotoxin and its relation to asthma in school-age children. $\mathrm{N}$ Engl J Med 2002;347:869-77.

38. Ege MJ, Mayer M, Normand AC, et al . Exposure to environmental microorganisms and childhood asthma. New Engl J Med 2011;364:701-9.

39. Ball TM, Castro-Rodriguez JA, Griffith KA, et al . Siblings, day-care attendance, and the risk of asthma and wheezing during childhood. N Engl J Med 2000;343:53843.

40. Samadi S, Heederik DJ, Krop EJ, et al . Allergen and endotoxin exposure in a companion animal hospital. Occup Environ Med 2010;67:486-92.

41. Jacobs JH, Krop EJM, Borràs Santos $A$, et al . Endotoxin exposure assessment in European schools: the HITEA school study. Indoor Air 2014;24:148-57.

42. Frankel M, Timm M, Hansen EW, et al . Comparison of sampling methods for the assessment of indoor microbial exposure. Indoor Air 2012;22:405-14.

\section{TABLES}


Table 1 Average levels of microbial markers in classrooms in three countries during 3 measuring periods

\begin{tabular}{|c|c|c|c|c|c|c|c|c|c|c|c|c|}
\hline & \multicolumn{4}{|l|}{ Spain } & \multicolumn{4}{|c|}{ The Netherlands } & \multicolumn{4}{|c|}{ Finland } \\
\hline & \multicolumn{2}{|l|}{ Index } & \multicolumn{2}{|c|}{ Reference } & \multicolumn{2}{|c|}{ Index } & \multicolumn{2}{|c|}{ Reference } & \multicolumn{2}{|c|}{ Index } & \multicolumn{2}{|c|}{ Reference } \\
\hline Number of schools in study & \multicolumn{2}{|l|}{6} & \multicolumn{2}{|l|}{2} & \multicolumn{2}{|l|}{5} & \multicolumn{2}{|l|}{6} & \multicolumn{2}{|l|}{4} & \multicolumn{2}{|l|}{2} \\
\hline Number of classroom samples & \multirow{2}{*}{\multicolumn{2}{|c|}{$\begin{array}{l}148 \\
56\end{array}$}} & \multirow{2}{*}{\multicolumn{2}{|c|}{$\begin{array}{l}51 \\
19\end{array}$}} & & & 164 & & 149 & & 60 & \\
\hline Number of pooled classroom samples & & & & & \multicolumn{2}{|l|}{40} & \multicolumn{2}{|l|}{57} & \multicolumn{2}{|l|}{46} & \multicolumn{2}{|l|}{22} \\
\hline Microbial markers & $\begin{array}{l}<\mathrm{DL} \\
\%\end{array}$ & $\begin{array}{l}\mathrm{GM}^{*} \\
\text { (GSD) }\end{array}$ & $\begin{array}{l}<\mathrm{DL} \\
\%\end{array}$ & $\begin{array}{l}\mathrm{GM}^{*} \\
\text { (GSD) }\end{array}$ & $\begin{array}{l}<\mathrm{DL} \\
\%\end{array}$ & $\begin{array}{l}\mathrm{GM}^{*} \\
\text { (GSD) }\end{array}$ & $\begin{array}{l}<\mathrm{DL} \\
\%\end{array}$ & $\begin{array}{l}\mathrm{GM}^{*} \\
\text { (GSD) }\end{array}$ & $\begin{array}{l}<\mathrm{DL} \\
\%\end{array}$ & $\begin{array}{l}\mathrm{GM}^{*} \\
\text { (GSD) }\end{array}$ & $\begin{array}{l}<\mathrm{DL} \\
\%\end{array}$ & $\begin{array}{l}\mathrm{GM}^{*} \\
\text { (GSD) }\end{array}$ \\
\hline \multicolumn{13}{|l|}{ Measured with EDC } \\
\hline Endotoxin (in EU/m² (GSD)) & 0 & $21638(1.96)$ & 0 & $20591(1.64)$ & 0 & $42957(1.78) t$ & 0 & $27031(1.63)$ & 0 & $1778(2.57) \neq$ & 0 & $1397(2.20)$ \\
\hline Glucans (in $\mathrm{ng} / \mathrm{m}^{2}$ (GSD)) & 0 & $8313(2.09)$ & 0 & $9293(2.47)$ & 0 & $13211(1.76) t$ & 0 & $10604(1.69)$ & 0 & $1366(2.42) \ddagger$ & 0 & $1098(1.97)$ \\
\hline \multicolumn{13}{|l|}{ Measured with SDB (in cell equivalents per SDBS/day) } \\
\hline Gram negative bacteria (b) & 0 & $82003(2.77)$ & 0 & $69382(2.09)$ & 0 & $59124(3.22) \dagger$ & 0 & 34569 (3.56) & 12 & $5170(6.51)$ & 5 & $8031(3.9)$ \\
\hline Gram positive bacteria (b) & 0 & $40524(2.79)$ & 0 & $49029(2.05)$ & 0 & $22482(2.85)$ & 0 & $16055(3.44)$ & 0 & $8057(4.13)$ & 0 & $11295(3.24)$ \\
\hline Ergosterol (f) (in ng/SDB/day) & 8 & $0.58(2.02) \dagger$ & 24 & $0.38(2.17)$ & 12 & $0.66(2.82)$ & 25 & $0.46(2.95)$ & $83 \pi$ & $0.08(0-0.86)$ & 959 & $0.01(0-0.58)$ \\
\hline Cladosporium herbarum (f) & 2 & $83(6.2)$ & 6 & $73(7.13)$ & 0 & $95(6.41)$ & 2 & $88(8.39)$ & 719 & $0.06(0-139)$ & 529 & $0.47(0-267)$ \\
\hline Mycobacterium spp. (b) & 9 & $2103(9.17)$ & 11 & $2379(10.12)$ & 0 & $5901(3.92)$ & 2 & 3992 (6.14) & $45 \pi$ & $39(0-24182)$ & $48 \pi$ & $33(0-16741)$ \\
\hline Penicillium chrysogenum (f) & $72 \pi$ & $2.35(0-1391)$ & $78 \pi$ & $0.57(0-7186)$ & $74 \pi$ & $2.26(0-1824)$ & $84 \pi$ & $0.84(0-828)$ & $93 \pi$ & $0.07(0-1596)$ & 100 & - \\
\hline $\begin{array}{l}\text { Group Penicillium spp/Aspergillus } \\
\text { spp/Paecilomyces varotï (f) }\end{array}$ & 0 & $3342(3.34) \neq$ & 0 & $5636(1.9)$ & 0 & $2261(3.68) t$ & 0 & $1162(3.47)$ & 29 & $66(13.8)$ & 43 & $31(22.24)$ \\
\hline Streptomyces spp (b) & 26 & $1181(9.61)$ & 39 & $511(14.14)$ & 9 & $6947(5.9) \neq$ & 11 & $3511(5.87)$ & 100 & $-\ddagger$ & $90 \AA$ & $0.49(0-3569)$ ก \\
\hline Stachybotys chartarum (f) & $98 \pi$ & $<0.1(0-38.53)$ & $94 \pi$ & $<0.1(0-556)$ & $94 \pi$ & $<0.1(0-7.19)$ & $93 \pi$ & $<0.1(0-22.82)$ & $98 \pi$ & $<0.1(0-5.2)$ & 100 & - \\
\hline $\begin{array}{l}\text { Group Trichoderma viride } \\
\text { atroviride/koningii (f) }\end{array}$ & $98 \pi$ & $0.13(0-1303)$ & 100 & - & 100 & - & $93 \pi$ & $14.13(0-704)$ & 100 & - & 95ף & $3.36(0-528)$ \\
\hline Wallemia sebi (f) & $98 \pi$ & $<0.1(0-387)$ & 100 & - & $65 \pi$ & $0.93(0-350) \neq$ & $82 \pi$ & $<0.1(0-670)$ & 100 & - & 100 & - \\
\hline Eurotium amstelodami (f) & 6 & $131(6.42)$ & 6 & $168(4.56)$ & 0 & $137(4.24)$ & & $120(4.36)$ & $45 \pi$ & $3.56(0-1348)$ & & $1.19(0-865)$ \\
\hline $\begin{array}{l}\text { Average number of detectable markers (minimum- } \\
\text { maximum) }\end{array}$ & \multicolumn{2}{|c|}{$7.8(6-10)$} & \multicolumn{2}{|c|}{$7.4(5-10)$} & \multicolumn{2}{|c|}{$8.4(6-10)$} & \multicolumn{2}{|c|}{$8.1(5-10)$} & \multicolumn{2}{|c|}{$4.2(1-7)$} & \multicolumn{2}{|c|}{$4.1(1-7)$} \\
\hline Average sum score (minimum-maximum) & \multicolumn{2}{|c|}{$13.1(4-25)$} & \multicolumn{2}{|c|}{$15.4(7-24)$} & $15(2-r)-3-2)$ & & 12.7 & & 13.3( & -25) & $13(3$ & \\
\hline
\end{tabular}


Jacobs, J., Borras-Santos, A., Krop, E., Täubel, M., Leppanen, H., Haverinen-Shaughnessy, U., Pekkanen, J., Hyvärinen, A., Doekes, G., Zock, J.P., Heederik, D. Dampness, bacterial and fungaty components in dust in primary schools and respiratory health in schoolchildren across Europe Occupational and Environmental Medicine: 2014, 71(10), 704-712

Table 2 General characteristics study population

\begin{tabular}{|c|c|c|c|}
\hline & Spain & Netherlands & Finland \\
\hline \multicolumn{4}{|l|}{ Basic characteristics } \\
\hline $\begin{array}{l}\text { Number of participants } \\
\text { (questionnaire survey) }\end{array}$ & 1121 & 1396 & 1326 \\
\hline Boys $(n, \%)$ & $588(52)$ & $658(47)$ & $615(46)$ \\
\hline Age (years, SD) & $8.9(1.8)$ & $9.1(1.8)$ & $9.9(1.8)$ \\
\hline Height (cm, SD) & $134(12.7)$ & $138(12.3)$ & $141(11.8)$ \\
\hline $\mathrm{BMI}\left(\mathrm{kg} / \mathrm{m}^{2}, \mathrm{SD}\right)$ & $17(2.8)$ & $16(2.3)$ & $18(2.8)$ \\
\hline Having an older sibling (n, \%) & $525(48)$ & $701(51)$ & $791(60)$ \\
\hline $\begin{array}{l}\text { Years of parental education } \\
\text { (year, SD) }\end{array}$ & $15.8(3.9)$ & $16.2(3.4)$ & $17.5(2.8)$ \\
\hline \multicolumn{4}{|l|}{ Passive smoking (n, \%) } \\
\hline Currently at home & $292(26)$ & $202(15)$ & $1(0)$ \\
\hline During 1 st year at home & $282(25)$ & $193(14)$ & $6(0)$ \\
\hline Maternal smoking during pregnancy & $180(16)$ & $132(10)$ & $56(4)$ \\
\hline \multicolumn{4}{|l|}{ Birth weight (n, \%) } \\
\hline$<$ than $2.5 \mathrm{~kg}$ & $101(9)$ & $94(7)$ & $63(5)$ \\
\hline $2.5-4 \mathrm{~kg}$ & $927(85)$ & $1045(77)$ & $1050(79)$ \\
\hline$>4 \mathrm{~kg}$ & $69(6)$ & $218(16)$ & $210(16)$ \\
\hline $\begin{array}{l}\text { Daycare attendance before } 6 \text { months } \\
(\mathrm{n}, \%)\end{array}$ & $148(13)$ & 470 (34) & $33(3)$ \\
\hline Parental history of asthma (n, \%) & $194(18)$ & $323(24)$ & $229(18)$ \\
\hline $\begin{array}{l}\text { Parental history of nasal allergies } \\
(\mathrm{n}, \%)\end{array}$ & $437(42)$ & $721(53)$ & $808(64)$ \\
\hline Parental history of skin allergies (n, \%) & $518(49)$ & $694(50)$ & 719 (57) \\
\hline Farm animal contact in 1st year (n, \%) & $63(6 \%)$ & $146(11)$ & $38(3)$ \\
\hline Pets present in home (n, \%) & $383(35)$ & $695(50)$ & $285(44)$ \\
\hline Moisture damage at home* $(\mathrm{n}, \%)$ & $198(19)$ & $256(19)$ & $54(4)$ \\
\hline \multicolumn{4}{|l|}{ Respiratory symptoms (n, \%) } \\
\hline Current wheeze & $117(11)$ & $132(9)$ & $171(13)$ \\
\hline Current congestion/phlegm, no cold & $68(6)$ & $119(9)$ & $136(10)$ \\
\hline $\begin{array}{l}\text { Current noctumal dry cough, } \\
\text { no cold }\end{array}$ & $227(21)$ & $259(19)$ & $162(13)$ \\
\hline Nasal symptoms, no cold & $255(23)$ & $318(23)$ & $423(33)$ \\
\hline Current asthmat & $45(4)$ & $77(6)$ & $111(8)$ \\
\hline
\end{tabular}



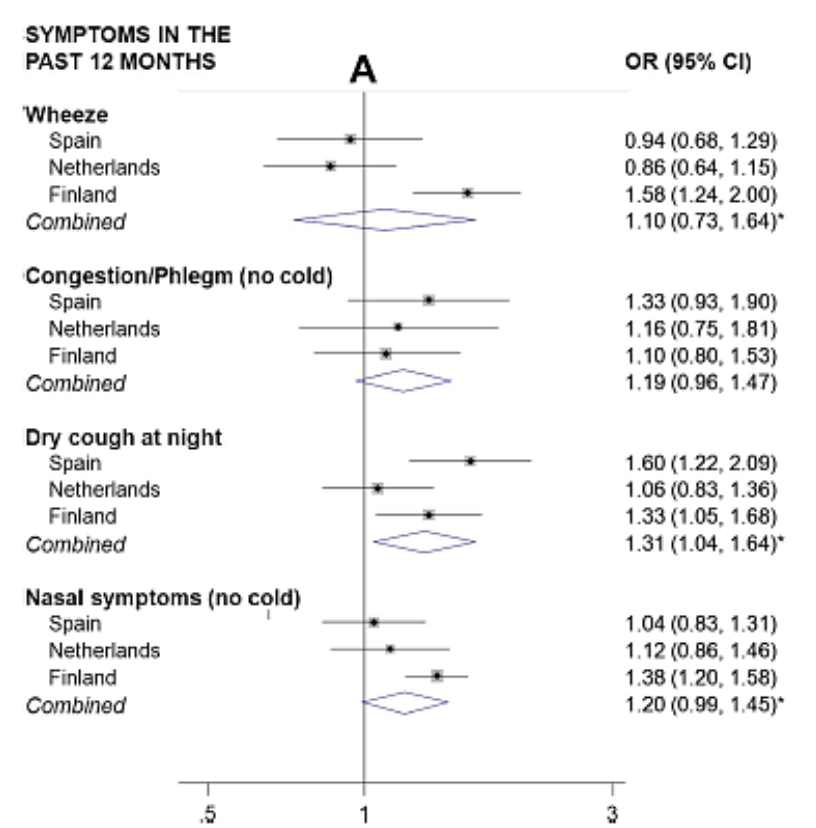

LUNG

FUNCTION

B

FEV1

Spain

Spain

The Ne

Finland
Combined

FVC

Spain

The Netherland

Finland

Combined

\section{FEF2575}

\section{Spain}

The Netherlands

Finland

Combined

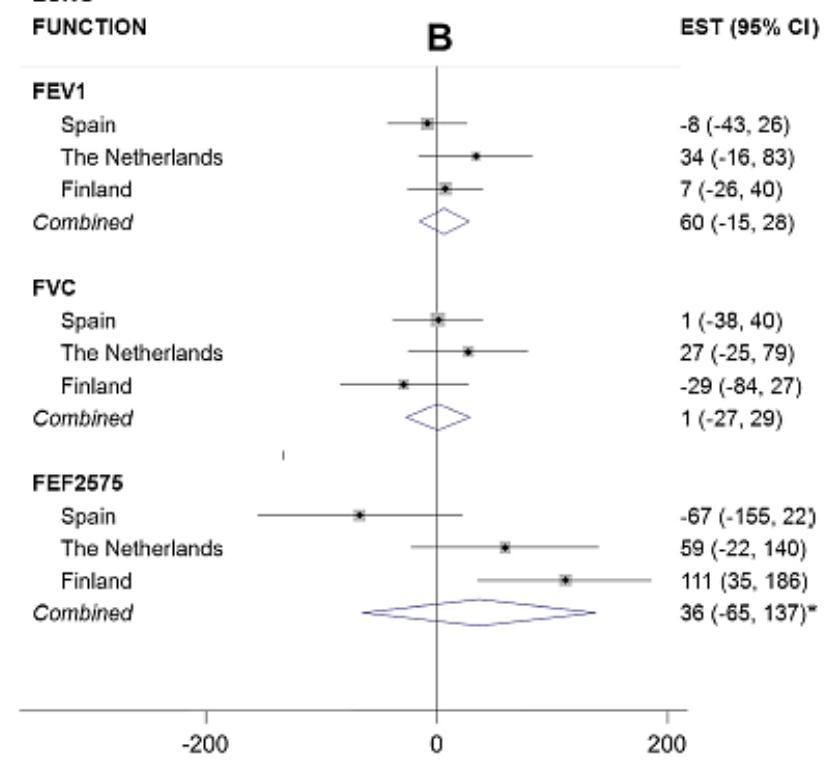

Figure 1 Association between moisture at school and respiratory health. Forest plots of country-spedific ORs and estimates (EST) (95\% Cl). The box area is proportional to the statistical weight for the individual study. The diamond indicates the $95 \% \mathrm{Cl}$ of the combined risk estimate from the model, with county as a random effect; ${ }^{*}=p$ for heterogeneity $<0.10$.

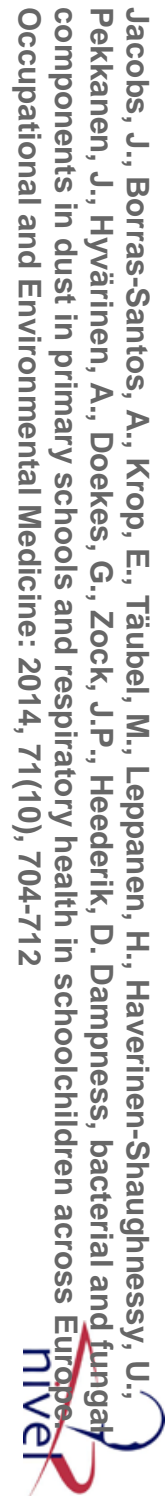


Jacobs, J., Borras-Santos, A., Krop, E., Täubel, M., Leppanen, H., Haverinen-Shaughnessy, U., Pekkanen, J., Hyvärinen, A., Doekes, G., Zock, J.P., Heederik, D. Dampness, bacterial and fungaty components in dust in primary schools and respiratory health in schoolchildren across Europe Occupational and Environmental Medicine: 2014, 71(10), 704-712
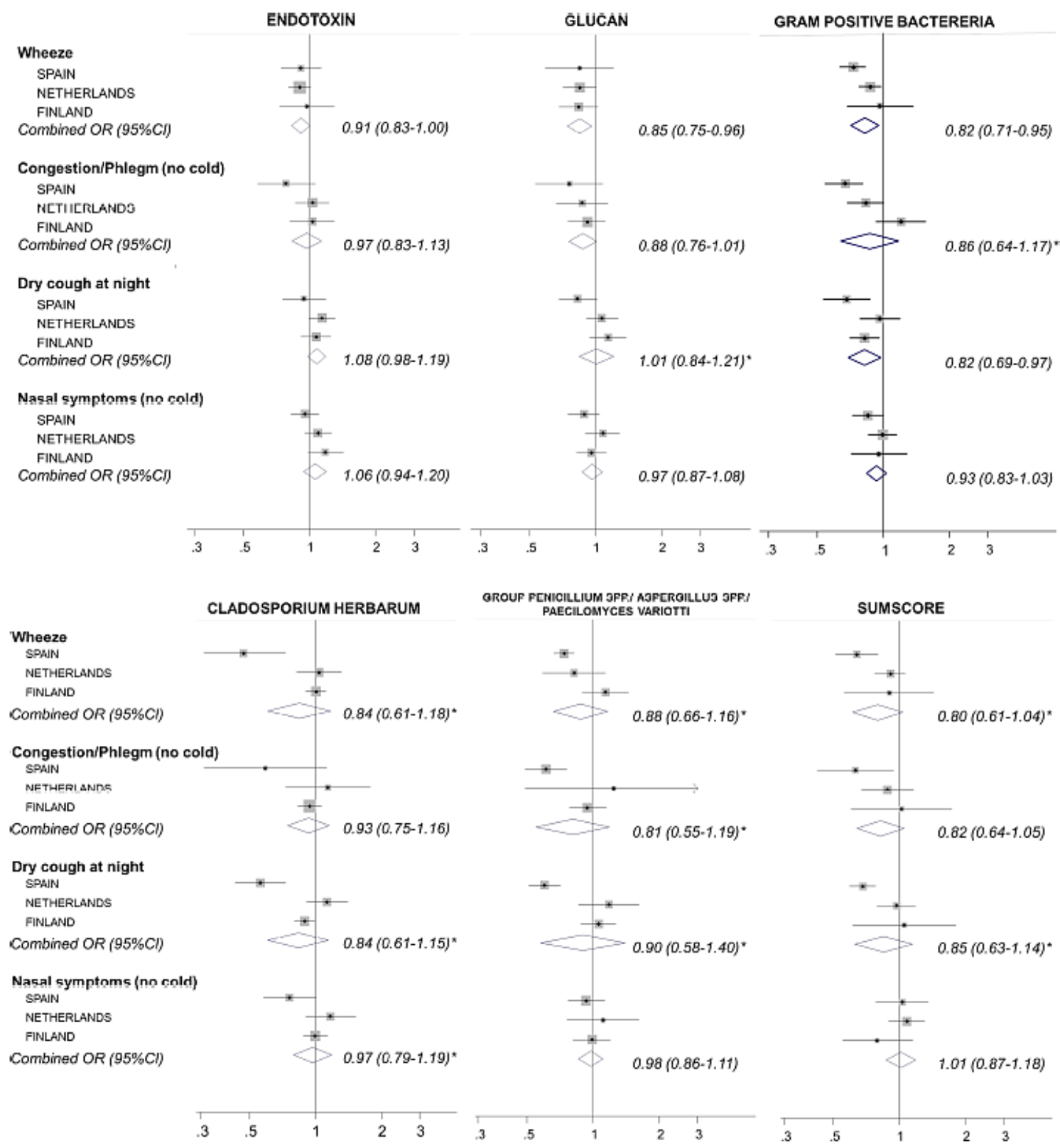

Figure 2 Association between measured microbial levels and symptoms, Forest plots of country-specific ORs ( $95 \% \mathrm{Cl})$ for the effect of measured microbial levels (IQR increase). The box area is proportional to the statistical weight for the individual study. The diamond indicates the $95 \% \mathrm{Cl}$ of the combined risk estimate from the model, with county as a random effect; * $=p$ for heterogeneity $<0.10$. 
Jacobs, J., Borras-Santos, A., Krop, E., Täubel, M., Leppanen, H., Haverinen-Shaughnessy, U., Pekkanen, J., Hyvärinen, A., Doekes, G., Zock, J.P., Heederik, D. Dampness, bacterial and fungaty components in dust in primary schools and respiratory health in schoolchildren across Europe Occupational and Environmental Medicine: 2014, 71(10), 704-712

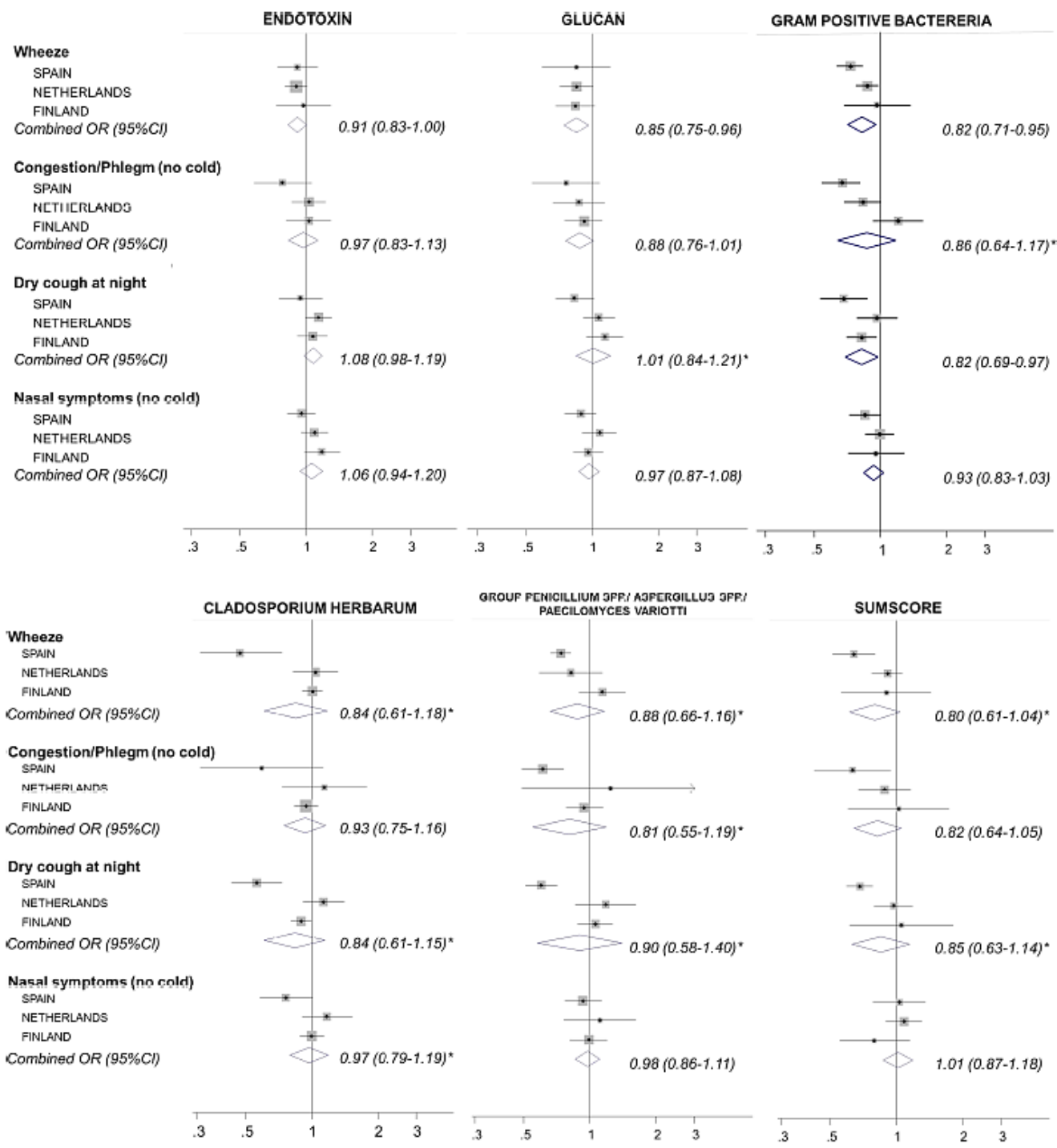

Figure 2 Association between measured microbial levels and symptoms, Forest plots of country-specific ORs ( $95 \%$ Cl) for the effect of measured microbial levels (IQR increase). The box area is proportional to the statistical weight for the individual study. The diamond indicates the $95 \% \mathrm{Cl}$ of the combined risk estimate from the model, with county as a random effect; ${ }^{*}=p$ for heterogeneity $<0.10$. 